\title{
Caminhos da Cena para a Educação Infantil
}

(1) aths of the Scene for Early Childhood Education 


\section{RESUMO}

O presente artigo consiste em apontamentos e reflexões que emergiram da parte prática da pesquisa de doutorado intitulada Colocando um novo ponto em cada conto: possibilidades de inserção do teatro na educação infantil. A pesquisa teve como objetivo central inserir o teatro na Educação Infantil através da contação de história e o do brincar. A peça $A$ Tempestade, de William Shakespeare, foi empregada como fio condutor de uma experiência cênica narrativa, pensada através da ambientação cênica e sonora do espaço escolar, como uma possibilidade de forjar uma experiência sensório-motora e artística para crianças entre três e cinco anos de idade. Foram realizadas apresentações em cinco centros de educação infantil na cidade de Dourados/MS. Com as apresentações foi possível comprovar que o brincar através do teatro e da contação de história tem um importante papel no desenvolvimento social, cognitivo, corporal e imaginativo da criança e do professor. A educação e o teatro juntas possuem o potencial de transformar, e esta transformação passa pelo individual e pelo coletivo.

Palavras-chave: contação de história; teatro; educação infantil; ambientação cênica e sonora; William Shakespeare.

\section{ABSTRACT}

The present article consists of notes and reflections that emerged from the practical part of the doctoral research entitled "Storytelling as a possibility of introduction theatre in early childhood education". The research has the main objective of inserting theater in Early Childhood Education through storytelling and play. William Shakespeare's play 'The Tempest' was used as the guiding thread of a scenic-narrative experience, thought through the scenic and sonorous setting of the school space, as a possibility to forge a sensory-motor and artistic experience for children between three and five years of age. Presentations happend at five Early Childhood Education Center in the city of Dourados. With the presentations, it was possible to prove that playing through theater and storytelling plays an important role in the social, cognitive, corporal and imaginative development of the child and the teacher. Education and theater together have the potential to transform, and this transformation passes through the individual and the collective.

Keywords: storytelling; theater; early childhood education; scenic and sound environment; William Shakespeare. 


\section{Introdução - Há muito tempo, em uma terra distante}

Era uma vez... uma professora que vivia em um reino muito distante, mas resolveu se aventurar por outras terras e ousou alçar novos vôos com a intenção de investigar formas de inserção do Teatro na Educação Infantil por meio da Contação de História. Essa professora acreditou ser importante trabalhar a expressividade e criação artística das crianças desde muito pequenas, e que uma das maneiras possíveis de fazer isso era deixar os pequenos transformarem o espaço e objetos que eles tinham contato diário, e assim fornecer estímulos para que aqueles pequenos "arteiros" pudessem produzir e conduzir seus próprios processos criativos.

Esta professora acreditava que a brincadeira é o motor que move a vida e o brincar é a parte mais importante da vida de uma criança. Ao brincar as crianças são espontâneas, estão inteiras e isso as ajuda a desenvolver as competências necessárias para a vida adulta, incluindo as relações interpessoais e profissionais:

Brincar não é apenas o ato ingênuo que os adultos acreditam sobreviver nas crianças, são os adultos que se tornam ingênuos não percebendo toda carga social e cultural que existe nos contextos das brincadeiras infantis (Gomez, 2012 p. 28).

A professora queria experimentar uma nova forma de brincar com as crianças, e escolheu um texto de um velho autor inglês que ela gostava muito para começar esta brincadeira séria. Este velho autor era muito conhecido pelo mundo inteiro, mas ao 
mesmo tempo desconhecido por todos, porque as pessoas achavam que ele falava muito difícil e tinham receio de ler suas obras. A Professora então resolveu juntar o brincar e o velho autor com uma outra paixão que ela possuía que era a contação de história, ela não sabia muito bem como iria fazer isso, mas depois de quase queimar seu cérebro de tanto pensar - chegou a sair até fumacinha - ela lembrou de um lugar onde seria possível juntar tudo isso: o teatro.

Um plano então começou a ser traçado pela professora. Este plano tinha como objetivo principal investigar maneiras e/ou metodologias de trabalho para inserir o teatro na vida das crianças que tinham entre 3 e 5 anos através da literatura Shakespereana, da Contação de História com objetos e da ambientação cênica e sonora, para aprofundar o estudo dos procedimentos utilizados na Pedagogia Teatral.

Mas para se chegar a este objetivo, foi preciso traçar vários outros objetivos menores que garantiriam o sucesso do plano. Para tanto foi preciso estudar muito, ler muito. Então, foi-se levantando temas que seriam importantes de se conhecer para a execução do plano, inicialmente foi preciso pesquisar o que os livros traziam sobre pedagogia teatral, sobre contação de história, sobre Shakespeare, sobre a criança pequena, sobre como os professores do reino entendiam o teatro e a contação de história, para que será que elas serviam? 
Como a professora era audaciosa, ela também pensou que para conseguir chegar no final de seu plano era preciso antes seguir pela estrada de tijolos amarelos e experimentar na prática como seria ir até as crianças e contar esta história para eles, usando o espaço, objetos e as próprias crianças para, através de uma grande brincadeira, que ela chamou de Experiência Cênica Narrativa, ou simplesmente, brincar de contar história.

Os apontamentos deste artigo versam sobre o trabalho prático que orreu entre março de 2017 e março de 2018, e abrangem a montagem e a apresentação da experiência cênica narrativa intitulada Era uma "Vez Shakespeare... E ele vai nos contar a história de uma Tempestade! ". Esta experiência foi apresentada em cinco centros de educação infantil e tinha como preceito deixar as crianças transformarem o espaço e objetos para suscitar estímulos, colocando-as como parte viva da narrativa que estava sendo contada, o que gerou a produção de processos criativos próprios de cada criança em cada turma apresentada.

As apresentações reforçaram a ideia de que o aprendizado só acontece de verdade quando ocorre alguma transformação do sujeito na sua relação com o mundo e com o outro, e isso acontece quando passamos pela experiência estética, quando experienciamos o sensível, quando a escuta ao outro está presente. Trabalhar com uma peça de Shakespeare possibilitou fugir um pouco do estereótipo das histórias infantis, e trabalhar com temas como o 
abandono, a vingança, a maldade, a ganância, entre outros, de forma lúdica, mesclando o novo e o tecnológico com o artesanal.

Toda a concepção cênica e sonora da experiência cênica narrativa partiu da ideia de que ambos seriam gatilhos ou dispositivos que produzissem estímulos sensoriais nos espectadores. Oferecendo materiais que estimulassem o pensar e a vontade de explorar nas crianças. Mas sem prever quais seriam as respostas das crianças a estas experiências - sem objetivos previamente definidos, abrindo espaço para a incerteza e o imprevisto - elas seriam diversificadas e inesperadas, logo os atores/contadores precisaram estar preparados para improvisar e lidar com o imprevisto.

\section{Desvendando os primeiros caminhos.}

Ouvir histórias, das mais variadas possíveis, é uma forma de construir uma porta de entrada para o imaginário. Um imaginário repleto de lugares, proezas e personagens, que levarão aqueles que ousarem abrir esta porta a viagens e aventuras incríveis.

Somos a construção de várias histórias, algumas nossas, outras que tomamos emprestadas. Não é à toa que não podemos datar, marcar no tempo, quando a contação de história começou e tão pouco poderemos dizer que ela um dia irá acabar. "A arte de contar histórias se confunde com a história da humanidade. O ser humano sempre precisou (e sempre vai precisar) ouvir e contar histórias: para se entender e para compreender sua relação com o mundo que o cerca" (Pessoa, 2015, p. 328). Claro que ao longo do 
tempo a função de se contar uma história foi se modificando, e hoje ela não é a mesma que era na antiguidade, seu papel social é outro e sua atividade acontece usando outros meios e de outras formas.

A arte de contar histórias se transforma de acordo com as mudanças do mundo e do homem, mas ela segue sempre em frente. Mesmo vivendo em uma atualidade onde as redes sociais e a internet prevalecem, e do exercício da escuta ser cada vez mais raro, todos nós temos a necessidade de contar ao outro o que nos passa, de exercer nossa oralidade. Porque não sabemos dizer ao certo se eu conto a minha história ou se é a minha história que me conta. Mas podemos afirmar que todos somos contadores de história:

Não há necessidade de ter o dom, pois essa é uma prática inerente ao ser humano, uma vez que contamos histórias o tempo todo: relatamos o que aconteceu durante o dia ao chegar à noite em casa; narramos um filme, um livro ou uma novela que nos emociona de alguma forma etc. É a emoção que nos move como contadores de histórias. Tudo o que nos causa paixão, seja ela como for, torna-se parte do nosso repertório como narradores. (Pessoa, 2015, p. 329)

Poucas coisas tem a particularidade de serem tão milenares e, ao mesmo tempo, tão contemporâneas como a contação de história. A arte de contar história foi sendo passada de geração em geração através da tradição oral e depois através da escrita ${ }^{\mathrm{i}}$. As histórias desde as bíblicas ${ }^{\mathrm{ii}}$ até as cotidianas foram por muito tempo uma forma de ensino dos costumes, da ética, condutas sociais, tradição e sabedoria popular. 
Ao longo dos anos contar uma história foi ganhando e perdendo diversos significados, se metamorfoseando, se aproximando e se afastando das formas tecnológicas e avanços científicos, mas sobrevive..., permanece... continua... e acredito que sempre continuará.

E ainda hoje, adultos e crianças (estes de forma mais visceral) quando escutam o "era uma vez..." começam a se transportar para um mundo particular, cheio de metáforas, memórias e fantasias, e se colocam em um estado de escuta, diferente do cotidiano e vão construindo um percurso próprio enquanto seguem o trajeto da narrativa que esta sendo contada, o exercício da escuta permite um diálogo com a obra e um passeio por suas significações de forma genuína.

Por isso, proporcionar a criança sair de suas carteiras e viverem uma aventura tem a potência de despertar nelas o gosto pela contação de história, pelo teatro e pelo aprender. Luciana Hartmann acredita ser importante trabalhar narrativas em aulas de teatro, especialmente com crianças, pelo fato de ser no corpo que "reagimos aos estímulos multissensoriais produzidos pela performance. E é ele que nos permite a atribuição de sentido" (2014. p. 234). Pois aprender sem ter a preocupação de aprender é muito mais divertido e orgânico logo, muito mais produtivo.

Logo a ideia foi trabalhar a teatralidade e as espacialidades na contação de história, criando oportunidades para vincular o fazer e o sentir através do corpo das crianças contrapondo-se a uma 
abordagem essencialmente verbal. Ou seja, o objetivo não era transmitir um conhecimento ou ministrar qualquer tipo de formação para os pequenos. Ao contrário o que se buscava era mesclar processo e produto, espectador e contador, realidade e fantasia.

Mas por que contar uma história de Shakespeare? Harold Bloom em seu livro Shakespeare: a invenção do humano coloca que "A resposta à pergunta 'Por que Shakespeare?' é: 'Quem mais haveria de ser'? (...) Ninguém, antes ou depois de Shakespeare, construiu tantos seres diferenciados. (2001, p. 25). Ele responde este questionamento logo no início do livro, e no final do mesmo retorna a questão dizendo:

Por que Shakespeare? Ele é o cânone ocidental, e começa a se tornar o centro do cânone mundial". (2001, p. 864) e ainda "Por que Shakespeare? Quem poderia substituí-lo, como artista que representa seres humanos? (2001, p. 876).

Trabalhar com uma peça de Shakespeare é proporcionar as crianças o contato com a obra de um dos maiores autores da história do teatro e do mundo. Talvez escolher contos, ou histórias mais 'apropriados para as crianças pequenas' seria mais fácil, no entanto, penso que o contador de histórias é também um divulgador de narrativas, de autores, de diferentes obras artísticas por ser o responsável em fazer a história chegar ao ouvinte.

A literatura de Shakespeare é, praticamente, única, ao combinar entretenimento e sabedoria. (...) afetivo x cognitivo; secular x sagrado; entretenimento $\mathrm{x}$ instrução; papéis dramáticos $\mathrm{x}$ 
personagens e personalidades; 'autor' x 'linguagem'; histórica $\mathrm{x}$ ficção; contexto x texto; subversão x conservadorismo. Shakespeare, em termos culturais, é a nossa maior contigência; Shakespeare é a história cultural que nos predetermina. (Bloom, 2001, p. 884)

Desta forma, como escolher uma história mais rica em termos de possibilidades e potencialidades de exploração e experimentação com crianças do que uma história escrita por Shakespeare? E ao mesmo tempo desmistificar a linguagem dita culta, de difícil entendimento dos seus textos e as temáticas não usuais na literatura infantil. Trabalhar as mais distintas temáticas e não apenas aquelas que são tradicionalmente consideradas do universo infantil (flores, palhaços, bichinhos, natureza, festas temáticas, etc.) é uma maneira de proporcionar as crianças a possibilidade de se aventurar por suas percepções e sentimentos e expressá-los através de diferentes linguagens.

Através de Shakespeare é possível trabalhar sentimentos que estão presentes em todas as relações humanas desde a primeira infância como raiva, alegria, amor, inveja, agressividade, solidariedade, ciúmes, solidão, abandono, afeto, amizade, entre outros. Estes sentimentos fazem parte do cotidiano das crianças, algumas vezes de forma ambivalente, e elas em geral ainda não entendem direito o que eles significam, como lidar com eles e como expressá-los.

Seus mais de 800 personagens sempre carregem em si o bem e o mal - diferente dos contos de fadas tradicionais onde existe 
o bom que luta contra o mal -, eles são mais humanos, mesmos aqueles que são apresentados como seres fantásticos, têm características humanas. Cada um deles tem consciência de que são responsáveis por seus atos, que surgem de escolhas, e que estas escolhas têm consequências.

\section{Primeiras escolhas - Dragões? Cavalheiros? Duendes? Não!!!!! Uma Tempestade.}

É a curiosidade que move o aprendizado, é através do brincar e do se encantar que a criança pequena se descobre e descobre o mundo à sua volta e vai aos poucos, no seu próprio tempo construindo processos de aprendizagem. A criança na Educação Infantil comprende o mundo usando todo seu corpo, sentindos e imaginação. Ela explora o mundo através de sua visão, audição e tato, e não sentada estática em uma cadeira com um lápis na mão reproduzindo letras que para ela não faz sentido algum.

O aprendizado na brincadeira nasce da espontaneidade, como algo natural e inerente ao brincar, a criança sem precisar racionalizar nada constrói conhecimento brincando. Na contação de história o processo é semelhante: ao ouvir uma história ou ao contar uma história a criança esta se divertindo e fazendo um jogo - seja de escuta ou de oralidade - que lhe permite o lúdico sem a intenção de gerar um aprendizado direto, sem cobranças ou avaliações do que foi entendido, sem gerar um produto palpável ou mensurável ao final. 
Na contação de história e no teatro o aprendizado, também, pode nascer naturalmente como consequência de uma narração permeada de ludicidade, seja na própria história, seja na atitude de quem narra. $\mathrm{O}$ encontro, a comunhão, a cumplicidade, a troca que se estabelece entre quem conta e quem ouve é o mais importante e o mais forte, o experimentar uma história e/ou uma brincadeira, ou melhor dizendo, o experimentar uma brincadeira através de uma história se opõe a lógica produtivista ou a ideia de que tudo tenha que ter uma utilidade.

A educação infantil tem um importante papel social na formação da criança, pois seu objetivo primeiro é a formação do sujeito, seu estar no mundo e sua relação com o outro. Na educação infantil se trabalha o reconhecimento, valorização e respeito de si mesmo e do outro. E tudo isto passa pelo brincar e pelo corpo:

"Ao descobrir as maneiras pelas quais podemos nos expressar corporalmente, descobrimos novas formas de nos movimentarmos, novas expressões e recursos que podemos utilizar na relação com outros corpos, nas relações sociais." (Faria, 2011. p. 127).

O aprendizado na primeira infância é potencializado quando esta inserido em ações que proporcionem a criação de situações ficcionais, de imitação e vivência de papéis sociais: "É ao brincar e fantasiar que a criança começa a entender o mundo, e, ouvir histórias também auxilia nesse processo onde realidade e imaginação se misturam". (Cunha, 2013, p. 3). Em especial na contemporaneidade, onde as relações de forma geral são mediadas 
por telas, e as atividades coletivas presenciais são cada vez mais raras a contação de histórias é uma oportunidade de aproximar as pessoas e fazê-las sonharem, sentirem, se emocionarem e se divertirem juntas.

A contação de história em si proporciona as crianças a descoberta do mundo através da apresentação e resolução de conflitos, logo trabalhar com um enredo como o de A Tempestade pode ser uma maneira de levar as crianças a refletirem de forma a aguçar e estimular o senso crítico. $\bigcirc$ enredo da peça problematiza a questão de causa e consequência, ação e reação, mostrando que nossas escolhas trilham nosso caminho. Elas podem ser boas, ruins, perigosas, benéficas, passíveis de elogios e/ou repreensão, mas sempre são frutos de nossas decisões e ações.

Escolher contar/brincar com a história de "A Tempestade" foi uma forma de trabalhar com duas qualidades - poder e perdão tão presentes nos dias de hoje, mesmo no univeso infantil. Todas as personagens da história estão atrás de algum tipo de poder, mas ao longo de seus caminhos descobrem a virtude do perdão.

É importante dizer que todo o trabalho foi desenvolvimento juntamente com meu grupo de trabalho/pesquisa. A ideia sempre foi ser fiel a história da Tempestade, mas a questão que se debateu muito foi a fidelidade ou não a peça escrita. Como falar com naturalidade usando uma escrita considerada por muitos como rebuscadas e de difícil entendimento? Como colocar a palavra em movimento? 
Segundo Heliodora "a Tempestade tem um certo ar de conto de fadas, de outro mundo e durante séculos foi considerada a "pecinha fácil de William Shakespeare" que as crianças lêem na escola, mas na realidade ela é uma maravilha de complexidade contada de uma maneira muito fácil". (2014)

Basicamente a peça fala sobre poder, sobre o bom e o mau uso do poder, cobrindo temas importantes como ilusão versus realidade, vingança, descoberta e redenção. Em uma primeira análise da peça podemos dividi-la em três núcleos: poder, comédia e romance. No entanto, quando começamos a aprofundar esta análise, descobrimos que toda a trama gira em torno da luta pelo poder, que aparentemente está mais presente em um dos núcleos, mas que permeia e conecta os três.

Toda a ação de A Tempestade acontece em uma ilha, ou seja, uma espécie de mundo a parte onde é permitido, quase como se por encantamento, que todos manifestem seus verdadeiros sentimentos. A ilha permite o encontro com o outro e a criação de uma teia de relações entre as personagens, uma teia de relações amorosas, filosóficas, sociais e políticas.

Próspero que é o grande arquiteto de toda a trama da peça, leva seus inimigos até a ilha motivado pelo desejo de vingança e poder. Ele quer fazer seus desafetos pagarem pelo que lhe fizeram, mas vai além, quer recuperar seu ducado e seu status de poder impetrando o príncipe de Nápoles como noivo de sua filha. 
Um ponto importante, desde o começo da pesquisa era a questão da recepção. Não queria de forma alguma que as crianças se sentassem confortavelmente e ouvissem de forma passiva a história que iria ser contada. Logo, um dos desafios durante o processo era pensar em uma recepção criativa. Mas do que ser alguém que assistirá uma história e elaborará - a partir da escuta uma interpretação da mesma, queria espectadores que participassem da história, construindo seus significados próprios.

O objetivo era quebrar a "quarta parede" na sala de aula e propor uma ação a partir da perspectiva ou pedagogia da experiência, estimulando e instigando a criança a fazer parte do processo. Desta forma, cada participante passaria por um tipo de fruição particular de acordo com a experiência que cada um construísse com o que estava sendo proposto. A criança, a partir de seus desejos e saberes faria a história reverberar de outras maneiras, construindo seus próprios significados, sem a preocupação de se chegar a uma racionalização do que foi feito, ficando no campo do sentir.

Com a história escolhida, era hora de pensar como ela seria contada. A experimentação prática partiu de uma certeza: eu queria estar imersa no ambiente diário das crianças, ou seja, a contação seria apresentada dentro dos CEIM's, explorando os espaços reais e possíveis que eles teriam para oferecer. Foi a partir deste espaço que eu, juntamente com o grupo de pesquisa, comecei a conceber toda a experiência cênica narrativa. 
Um ponto importante, e já definido previamente, era de que nosso público (as crianças) não ficaria passivo durante a contação, eles fariam parte da história, vivenciariam e experimentariam com seus corpos o que estavam escutando. A criança usa o corpo para se expressar, e isso acontece o tempo todo, é através do corpo que elas dizem aos adultos como se sentem, o que querem, o que não querem, o que pensam, etc. Nós ocupamos espaços e fazemos parte do mundo através de nosso corpo, é a partir dele que aprendemos, que nos comunicamos, que sentimos, exploramos e interagimos com o outro e com o mundo.

A próxima decisão tomada foi que o público iria ficar no meio da sala. Eles estariam no centro da ação e todo o resto (narração e cenas) aconteceria ao redor. Esta disposição do espaço também serviria para que a todo momento as crianças fossem instigadas e chamadas para direcionar seus olhares e corpos para um espaço diferente do ambiente, ou seja, quebrando a ideia de espectador como alguém que se posiciona sentado e inerte para assistir algo que acontecerá à sua frente.

Como dito acima, toda a ação da peça se passa em uma ilha, a partir deste fato surgiu a ideia de dividir o enredo em núcleos e fazer as crianças experimentarem a sensação de também estarem nesta ilha e ela estar dividida em partes. Esta divisão proporcionou um melhor entendimento do enredo por parte das crianças, por ser uma forma de identificar os núcleos e os personagens. Cada núcleo foi trabalhando com uma cor diferente, simbolizando a divisão da 
ilha, e para tanto foram escolhidos tapetes para materializar estes espaços e cores.

Foram escolhidas cinco cores de tapetes: azul, vermelho, verde, marrom e laranja. $O$ tapete azul ficaria ao meio, onde as crianças estariam (pelo menos na maior parte do tempo); o tapete vermelho ficaria na entrada da sala a direita, e representaria a parte da ilha onde Próspero e sua filha Miranda viviam; o tapete verde ficaria à direita ao fundo, e representaria a parte da ilha onde estão os nobres; o tapete marrom ficaria ao fundo à esquerda e representaria o lugar da ilha onde vive Caliban e onde ele se encontra com Trínculo e Estefano; o tapete laranja seria posicionado na parte da frente à esquerda e representaria a parte da ilha onde Ferdinando estava perdido. Decidimos que Ariel (espírito do ar) seria o único a circular livremente por todos os núcleos/partes da ilha.

Também decidimos que todos atuariam como narradores da história, hora enquanto personagens que narravam sua história, hora como narradores aparte do enredo, e ainda em determinados momentos seriam atores que improvisam pequenas cenas. Desta forma misturamos narração com encenação, contação de histórias com teatro. E os atores/contadores iam transformando o espaço e os objetos em pedaços e lugares da história.

Aos poucos foi sendo delineado o que seria mostrado, o que seria narrado e o que seria instigado para ser imaginado pelas crianças. Augusto Pessoa coloca que o "o fazer teatral é um espaço 
propício para a magia e o encantamento" (2015. P 328), acredito que a mistura destas duas potências - teatro e contação - é uma forma de enriquecer ainda mais este espaço.

O desejo de contar com a palavra, com o gesto, com objetos, com adereços, com sons, etc., foi ganhando força, forma e a certeza de que cada criança que participasse da experiência cênica narrativa poderia também andar pela história e viver uma experiência que tivesse o potencial de ser preenchida e reinventada com seus próprios significados, códigos e interpretações, agregando e construindo um conhecimento através das cores, dos sons, das formas, das texturas, dos cheiros, etc.

Inspiradas nas palavras de Melissa Ferreira sobre o Teatro da Sociètas Raffaello Sanzioiv começamos a projetar como seria nosso espaço:

O espaço do jogo e da ficção era rigorosamente pensado para envolver todos os sentidos da percepção e para que a consciência do ato teatral pudesse fruir naturalmente e de forma direta em cada criança. Para Guidi, "o teatro é o lugar onde, se a ficção é conscientemente jogada, podese experimentar um outro mundo. $O$ teatro dá as provas daquilo que se conta, porque se experimenta efetivamente. $O$ jogo dá às crianças a possibilidade de transformar em ação a imaginação: somente quem entra no jogo pode 'ver'". (2016, p. 12)

Se de acordo com a citação acima "o teatro dá as provas daquilo que se conta, porque se experimenta efetivamente" era preciso pensar em um espaço para a contação que trouxesse uma atmosfera dramática capaz de possibilitar as crianças "transformar 
em ação a imaginação". Era isso que eu queria fazer, mas com a contação de história.

A criança não iria necessariamente contar a história ou uma história, mas a ideia era que ela participasse ativamente da contação através de jogos e brincadeiras, e com isso acabaria interferindo na história. Logo a ambientação cênica e sonora, e os objetos seriam de suma importância para que pudessem ativar a memória afetiva ou vir a se tornar uma memória afetiva dos participantes, o que poderia permitir que essa experiência se fixasse na memória criando registros através do brincar na contação.

Ao mesmo tempo o ambiente precisaria ser de cumplicidade e confiança para que as crianças se sentissem seguras para brincarem nele. Este foi um dos motivos que me levaram a escolher que as apresentações deveriam acontecer no espaço que as crianças frequentavam todos os dias, como dito acima nos centros de educação.

No entanto, era preciso criar uma atmosfera diferente da cotidiana para ajudar a despertar e instigar a curiosidade e a imaginação ao que seria contado. Girandello (2011), citando Kieran Egan, diz ser necessário existir uma dialética entre o familiar e o exótico, pois "quanto mais distante e diferente da experiência cotidiana das crianças alguma coisa for, mais atraente à sua imaginação ela tenderá a ser" (p. 86), mas que a familiaridade com o local é de suma importância, "a ênfase nos extremos e nos limites 
não nos afasta da experiência cotidiana, mas permite vê-la sob uma nova luz" (p. 86).

Eram muitos elementos a serem pensados. O que eu buscava era uma ambientação cênica conectada com o contexto de ficção da história, capaz de gerar material que dessem suporte a narrativa, transmitissem segurança para as crianças e envolvessem os pequenos com estímulos visuais, sonoros e táteis. Tudo isso por acreditar que ao abranger aspectos plásticos, audiovisuais, musicais e linguísticos, o trabalho seria capaz de mobilizar as dimensões sensório-motora, simbólica, afetiva e cognitiva da criança.

A arquitetura foi usada como referência para fazer associações entre o espaço onde os personagens se encontravam presos, ou seja, uma ilha, e a sala de aula onde os alunos se encontram "presos" na maior parte de seu dia.

Karina de Castilhos Lucena em seu ensaio sobre os conceitos de Bachelard (A Poética do Espaço), coloca que é "Através do espaço se pode chegar a uma fenomenologia da imaginação, ou seja, conhecer a imagem em sua origem, em sua essência, sua pureza" (2007, p. 01). Como o objetivo era buscar o envolvimento dos participantes através da materialidade concreta dos objetos apresentados, foi necessário criar nas crianças um envolvimento emocional com o universo de ficção: "o exterior somente é entendido quando transformado em interior, e não pensar dessa forma leva a generalizações descabidas. Tudo é valor 
humano; O espaço não pode ser unicamente exterior pois é vivido, imaginado, recordado interiormente" (2007, p. 9).

A partir deste pensamento, ficou decidido que seria importante trabalhar com uma materialidade que pudesse perpassar os cinco sentidos (tato, audição, visão, paladar e olfato) como forma de impulsionar o processo dramático da contação. A história seria encontrada e tecida aos poucos pelos contadores e pelas crianças.

É importante dizer que todas estas intenções e objetivos deveriam ser alicerçados no ato de brincar, em jogos e/ou brincadeiras do universo infantil. Klisys coloca que possibilitar que a criança realize diversas brincadeiras a partir de cenários variados é uma "contribuição importante para alimentar as intenções lúdicas que se estabelecem, porque isso oferece um contexto para a brincadeira acontecer de formar mais complexa" (2010. p. 53). Foi então que me recordei de algo simples, mas que me encantava quando criança e que resiste ainda hoje: o túnel.

Em muitos parques públicos com espaços reservados para crianças existe um túnel de concreto para elas atravessarem e/ou escorregadores fechados, em forma de túnel. Nos parques fechados (shoppings e casas de diversão infantis) existem brinquedos com túnel. Em programas infantis existem provas onde as crianças devem atravessar por um túnel, enfim... os exemplos são vários, e achei que era uma boa ideia para começar a contação, pois a ideia de adentrar um túnel me parecia uma boa forma de "mexer" com a imaginação das crianças. Gardner apud Girandello diz que "a imaginação, como 
a inteligência ou a sensibilidade, ou é cultivada, ou se atrofia" (2011, p. 76).

Após algumas experimentações ficou decidido que nossa história começaria com um dos atores/contadores indo até a sala de aula das crianças e convidando-as para participar de uma aventura, onde elas teriam que passar por um teste de coragem: atravessar uma tempestade. Foram distribuídas lanternas para cada uma das crianças e elas entraram com um dos atores/contadores em um túnel escuro onde vivenciaram a tempestade. Do lado de fora outros atores/contadores faziam sons que remetiam a uma tempestade em alto mar (trovões, raios, vento, chuva, mar agitado, etc), enquanto diziam algumas frases do início da peça.

O convite para as crianças entrarem no túnel já foi uma forma de despertar a curiosidade para adentrarem no desconhecido e viverem uma aventura, também foi um ato de intencionalidade, cada criança pode escolher se queria ou não entrar no túnel. Participar de uma tempestade dentro de um túnel confeccionado com pano preto, é a simulação de uma realidade, mas com elementos concretos que permitem a imaginação e a criatividade.

Ficou decidido que cada criança poderia escolher se queria atravessar o túnel ou se queria ficar ao lado de fora do mesmo. Para aquelas que escolhessem ficar ao lado de fora do túnel foi feito o convite para que eles ajudassem os atores/contadores a fazerem os efeitos sonoros da tempestade. Para tanto, foram disponibilizadas chapas de raio $x$, pau de chuva e folhas de papel oficio, além dos 
sons feios com a boca, despertando o ineress e a curiosidade tanto nas crianças que escolheram entrar no túnel, como naquelas que escolheram ficar fora do túnel.

Quando o mar e a tempestade se acalmam, as crianças são convidadas a pegarem seus botes (barcos de papel - dobradura pendurados ao longo do túnel, mas ainda não abertos) e saírem do túnel. A saída do túnel dá para a porta de entrada da sala, na porta as crianças são convidadas a deixarem suas lanternas em um caixote de madeira e abrirem seus botes para conseguirem chegar até a ilha. Com os botes nas mãos e orientadas por um dos atores/contadores todos vão navegando pela sala e descobrindo a ilha, até se sentarem ao meio (tapete azul).

Em cada núcleo da ilha (tapetes) existia um cabideiro de chão com os acessórios que iriam caracterizar cada personagem no decorrer da experiência cênica narrativa. Ficou decidido o uso de três acessórios e/ou objetos para cada personagem. Nos núcleos também estão ou uma escada (caracterizada para simbolizar uma árvore) ou praticáveis (cubos de madeiras). Os atores/contadores estão com um macacão, cada um de uma cor como roupa base para fazer o narrador e colocam os acessórios/objetos cada vez que vão fazer uma personagem. Todos passam pela função de narrador e de personagem durante a experiência cênica narrativa.

Com todos - espectadores e atores/contadores - dentro da sala, os cinco atores/contadores recepcionam as crianças e começam a apresentar Shakespeare e discorrer sobre a história, uma 
espécie de introdução antes de começar a narração propriamente dita. A interação entre público, história e os atores/contadores acontecem no decorrer de toda a apresentação, as crianças são instigadas a participar, a se relacionar com objetos, parte do cenário, figurinos. São convidadas a cantar, dançar, brincar, jogar, se locomoverem de uma parte da ilha para outra, comer frutas e beber sucos "mágicos", etc. E de forma natural as crianças se apropriam da história, se transformando em personagens e/ou cúmplices dos atores/contadores, brincando e fazendo teatro.

Em todos estes momentos foram disponibilizados elementos e sonoridades que deslocamram as crianças entre realidade e ficção, com o objetivo dos espectadores serem envolvidos e estimulados a construir suas próprias imagens da história. Imagens estas que são desencadeadas a partir do espaço e de sua ambientação.

De acordo com Flávio Desgranges (2006) o espectador não é alguém que assume uma postura passiva em frente a obra de arte, mas sim alguém que está lá para elaborar uma interpretação própria e particular da obra. $O$ entendimento de determinada obra artística não está dado como imutável por seus criadores, pelo contrário está constantemente sendo construído e reconstruído por seus espectadores através de um ato criativo, produtivo e autoral.

Para finalizar a apresentação cada um dos cinco atores/contadores fica com um grupo de crianças e vai estimulando para que elas escolham personagens favoritos das histórias que elas conhecem; para que elas contem histórias que conheçam; e para 
que escolham desenhos que simbolizem esses personagens. Os atores/contadores, usando como material lápis pinta cara, fazem desenhos nas crianças, em suas mãos, rostos, ombros, etc. assim como as próprias crianças também desenham nos atores.

\section{Alguns apontamentos}

É importante deixar claro que cada experiência cênica narrativa realizada foi única e singular. Com diferentes reações e interações por parte das crianças e dos atores/contadores. A sala, que era uma sala de aula comum, passava a fazer parte da narrativa ao se transformar em uma ilha. E as crianças alternavam o papel de espectador e performer durante todo o processo que mesclava narrativa e performance.

Os alunos interagiam o tempo todo e em cada intervenção o trabalho de improviso e o trabalho em grupo era essencial, todos sabiam o que deveria ser feito e se caso alguém se perdesse o outro estava ali para colaborar com a cena. Várias cenas foram modificadas pelos alunos e isso era tudo que queríamos. Tivemos crianças agitadas, tivemos crianças desanimadas, chorosas, com necessidades especiais, e trabalhávamos com cada um desses sentimentos, convidando-os a brincar com a gente e deixando espaço para que eles fizessem parte da história da forma que quisessem ou pudessem.

As crianças foram colocadas durante toda a ação como sujeitos, que vivem e pensam de um modo próprio, mas digno de 
ser escutado e respeitado. Seres com autonomia e atuantes diretos no processo de ensino-aprendizagem. Toda a ideia desta experiência com as crianças foi baseada na vontade de que elas atuassem como interlocutoras e como criadoras da história que estávamos vivendo.

Não estávamos apresentando um espetáculo de teatro linear sem interação, estávamos brincando e contando histórias para crianças, exercitando seu imaginário. Passamos por alguns desafios como espaço de sala e climatização, alguns CEIM's tinham salas menores que as outras e nosso cenário precisava ser readaptado no espaço que tínhamos e isso fazia com que em cada chegada no CEIM fosse um novo desafio. O espaço não era só diferente para as crianças a cada apresentação, era diferente para os atores/contadored também, claro que esta diversidade era parte do plano e trabalhar com o imprevisto foi algo previsto desde o início.

Não ocorreu em nenhum momento a busca por um entendimento racional da história, mas sim a busca por um entendimento construído a partir dos sentidos, da relação do corpo com o espaço, dos sentimentos despertados, provocando interstícios no já conhecido e despertando a imaginação para o desconhecido.

Imaginar é pensar na realidade não do jeito que ela é, mas do jeito que ela poderia ser, é pincelar com mágica a realidade conhecida e colorí-la de possibilidades. Imaginar é uma forma de inventar o impossível. Imaginar a partir de diferentes estímulos 
sensoriais vai muito além de uma troca de infomação, forja vínculos. Constuir um sentido para história a partir destas duas qualidades imaginação e corpo como ambiente de cognição - é diferente do que aceitar um sentido atribuído por outros, e infinitas vezes mais rico.

Ou seja, como coloca Girandello "as vivências imaginativas da infância têm um papel crucial no seu desenvolvimento estético, afetivo e cognitivo" (2011. p. 90) que vão além da recepção de uma mensagem ou da emissão de um significado sobre a história que foi experienciada:

A experiência é, para Benjamin, forjada e tecida artesanalmente com os materiais fornecidos pela vida, e é transmitida através da narrativa, "ela própria, num certo sentido, uma forma artesanal de comunicação. Ela não está interessada em transmitir o 'puro em-si' da coisa narrada como uma informação ou um relatório". O narrador é aquele que está imbuído de suas próprias experiências e também das experiências alheias, é aquele que, através de uma relação artesanal, trabalha a sua matéria, a vida humana, transformando-a num produto "sólido, útil e único". (Ferreira, 2016. p. 152)

Assim, foi oferecida as crianças que participaram tempo para que cada uma delas pudesse assimilar a experiência cênica narrativa à sua própria maneira, sem a obrigatoriedade de ter que tentar racionalizar através de palavras ou desenhos, cada uma levou consigo sensações que experimentaram e uma pintura em seus corpos de personagens de suas histórias e não, necessariamente, da história que foi contada. A busca foi pela subjetividade, a sensibilidade e a imaginação e não a objetividade e a razão. 
A experiência cênica narrativa envolveu todos os participantes sensorialmente, cada um vivenciou uma experiência que passou por todos os seus sentidos, cada criança e sentiu parte da história que foi narrada, encenada e vivida, construindo assim um aprendizado a partir e através do que foi vivenciado no contexto ficcional dentro de um espaço de criação e brincadeira.

Para a proposta do trabalho acontecer foi preciso disponibilidade das crianças, para entrarem na brincadeira, tocar e deixar-se tocar pela ambientação cênica e sonora, e se inserir na história. Desta forma foi possível aguçar os sentidos e a percepção, provocando o sentir e não o pensar de forma racional. Construir um espaço que imprimisse segurança ao mesmo tempo que as instigasse foi fundamental para que as crianças se entregassem ao livre brincar com a história e se relacionassem de forma real com o contexto ficcional que foi instaurado, imergindo no brincar.

Durante as apresentações o olhar dos pequenos não foi diretamente direcionado, foram dadas indicações, mas se uma criança quisesse se levantar e ir até um dos núcleos da ilha ou até mesmo sair da sala, esta não era impedida de fazê-lo. Justamente por este motivo, se fez necessário uma conversa com as professoras e auxiliares de sala, onde o grupo deixou claro o pedido/demanda de que elas não interferissem, não solicitassem as crianças que ficassem sentadas e/ou em silêncio, tão pouco lhes chamasse a atenção por qualquer atitude que elas viessem a tomar. 
Para funcionar a ideia do brincar, era preciso deixar as crianças livres para entrarem ou não na brincadeira, para olharem ou não em direção a alguma cena ou narrativa, a aceitarem ou não brincar com a gente.

O foco estava na escuta, mas também estava na visão, na percepção tátil, nos cheiros e gostos. A proximidade física com as crianças permitiu que elas tocassem, pegassem, puxassem e enxergassem os atores/contadores e a materialidade de seus corpos, suscitando uma cumplicidade e uma comunhão entre eles. Esta intimidade gerou confiança, e eles se sentiam de fato convidados a também fazer parte do que estava acontecedo, aos poucos foram sendo dissolvidas as fronteitas entre produção e fruição. Não existiu a ideia de palco neste processo, os atores/contadores e as crianças foram parte integrante da história, sem evidência de ambas as partes. Foi pedido as professoras para que não interrompessem a contação caso alguma criança viesse a chorar ou até "atrapalhar" a cena. Era nossa tarefa enquanto atores/contadores encontrar maneiras de jogar com a criança sem forçá-la a fazer o que não quisesse.

Outro fator que considero importante foi terminar a história sem esperar ou permitir que ouvesse espaço para aplausos ou conversas sobre o que acabaram de presenciar. A história termina com todos sentados próximos uns dos outros e de imediato as crianças são convidadas - por aquele ator/contador que estiver mais 
próximo delas - a contarem uma história também. Nós viemos aqui para contar, ouvir e fazer uma história com vocês.

Quando pensamos nas práticas de ensino do teatro nos espaços de educação, sejam eles formais ou não formais, temos que pensar no teatro contemporâneo, e propor uma construção de conhecimento que insurja da experiência provocada pelo jogo e pelo fazer teatral, não ficando presos em regras ou metodologias como se fossem receitas prontas. Ao contrário são possibilidades e devem ser revisitadas sempre, mas com um olhar que converja na prática artística do próprio professor de teatro.

É comum observar nos processos de ensino do teatro, mesma quando propostos por artistas, em contextos formais e não formais, o recurso a antigas metodologias de ensino que se resumem na instrução de conteúdos como as convenções do teatro, certos sistemas de atuação, ou montagem de peças a partir de textos dramáticos ou improvisação. Apesar de realizarem trabalhos pessoais alinhados com a cena contemporânea, muitos professores-artistas desconhecem formas de realizar atividades com os alunos que se aproximem de suas práticas sem que se engrente o caos, o espontaneísmo e a sensação de que não está indo para lugar nunhum. A lógica da prática, que muitas vezes já é aplicada pelos artistas em seu trabalho, não funciona em suas propostas pedagógicas. (Ferreira, 2016. p. 164)

Entendo que no dia a dia da sala de aula, tendo que cumprir uma carga horária alta, preencher planos e diários, planejamentos, reuniões, seguir parâmetros, diretrizes e base curricular, o professor por vezes se sente sem espaço e/ou tempo para criar com sua turma algo novo. No entanto, temos sempre que ter em mente que o 
caráter educacional da arte nasce justamente da experiência (Dewey, 1934), certos saberes só aprendemos fazendo, só aprendemos ao passar pela experiência do fazer.

A atividade de contar história e/ou fazer teatro é de suma importante no ambiente escolar, principalmente nos anos iniciais, pois estas atividades tem o poder de transformar e de colaborar no desenvolvimento infantil, seja ele social, cognitivo, corporal ou imaginativo. O professor é aquele que pode propor formas significativas de experiência para o aprendizado da criança e é sempre uma via de mão de dupla, um aprende com o outro. É nesse sentido que a contação de história pode colaborar para um ser pensante e menos racional e os dias atuais de nossa sociedade brasileira pedem por mais alegria e imaginação.

Pensar na construção dos sentidos a partir de uma teoria prática que nasce da prática teórica, ambas ligadas a experiência. A experiência ou o experienciar algo suscita pensamentos. Os pensamentos são provenientes de algo prático, mas apoiados em teorias, seja as teorias de quem passou pela experiência, seja daqueles que proporcionaram ou provocaram a experiência. Por isso, a teoria e a prática alimentam a experiência ao mesmo tempo que se alimentam dela. 


\section{REFERÊNCIAS}

BACHELARD, Gaston. A poética do Devaneio. São Paulo: Martins Fontes, 2009.

BACHELARD, Gaston. A poética do espaço. São Paulo: Martins Fontes, 1993.

BENJAMIN, Walter. Reflexões: a criança, o brinquedo, a educação. São Paulo: Summus, 1984.

BETTELHEIM, Bruno. A psicanálise dos contos de fadas. 9 ed. RJ: Paz e Terra, 1980.

BLOOM, Harold. Shakespeare: a invenção do humano. Tradução de José Roberto O'Shea. Rio de Janeiro: Objetiva, 2001.

CUNHA, Gabriela Duarte. A importância da contação de histórias e da leitura em voz alta para crianças em fase de alfabetização. Cadernos do CNLF, Vol XVUU, $n^{\circ} 06$. Rio de Janeiro: CiFEFiL, 2013.

DESGRANGES, Flávio. A pedagogia do teatro: provocação e dialogismo. São Paulo: Editora Hucitec : Edições Mandacaru, 2006.

DEWEY, J. Art as experience. New York: Minton, Balch \& Co., 1934.

FARIA, Alessandra Ancona de. Contas histórias com o jogo teatral. São Paulo: Perspectiva, 2011.

FERREIRA, Melissa. Isto não é um ator: o teatro da sociètas Raffaello Sanzio. São Paulo: Perspectiva, 2016.

GIRANDELLO, Gilka. Voz, Presença e Imaginação: A Narração de Histórias e as Crianças Pequenas. Florianópolis: UFSC, $2007 . \quad$ In http://www.nica.ufsc.br/index.php/publicacoes/gilka. Acessado em 22 de maio de 2017. 
GIRANDELLO, Gilka. Imaginação: arte e ciência na infância. Campinas: Pro-Posições, 2011. v. 22, n. 2 (65), p. 75-92, maio/ago. Disponível

https://periodicos.sbu.unicamp.br/ojs/index.php/proposic/article/view/86432 63/0 acessado em 30 de julho/2017.

GOMES, Lenice, MORAES, Fabiano (org). A arte de encantar: o contador de histórias contempoâneo e seus olhares. São Paulo: Cortz, 2012.

HELIODORA, Barbara. Por que ler Shakespeare. São Paulo: Globo, 2008.

HELIODORA, Barbara. A Evolução de Shakespeare. 2014. Disponível:

https:/www.youtube.com/watch?v=e9rs2DgpI98 - acessado em 10/09/2017.

KOUDELA, I. Jogos Teatrais. São Paulo, Perspectiva, 1984.

KLISYS, Adriana. Quer jogar?. São Paulo: Edições SESC SP, 2010.

LARROSA, Jorge. Notas sobre a experiência e o saber de experiência. Universidade de Barcelona/Espanha. Tradução de João Wanderley Geraldi. Campinas: Revista Nacional de Educação, 2001. Disponível em: http://www.scielo.br/pdf/rbedu/n19/n19a02.pdf. Acesso em diversas datas.

LUCENA, Karina de Castilhos. Uma fenomenologia da imaginação através do espaço. In Revista Eletrônica de crítica e teoria de literaturas. Porto Alegre: PPG-LET-UFRGS. v 03, n 01. 2007.

MEDEIROS, Fábio Henrique Nunes e MORAES, Taiza Mara Rauen (org). Contação de histórias: tradição, poéticas e interfaces. São Paulo: Edições Sesc São Paulo, 2015.

PESSOA, Augusto. Teatro e Contação de História. In MEDEIROS, Fábio Henrique Nunes e MORAES, Taiza Mara Rauen (org). 
Contação de histórias: tradição, poéticas e interfaces. São Paulo: Edições Sesc São Paulo, 2015. p. 328-335.

RAMOS, Ana Claudia. Contação de histórias: um caminho para a formação de leitores? Dissertação de Mestrado em Educação. Universidade Estadual de

SHAKESPEARE, William. A Tempestade. Tradução e adaptação de Sonia Rodrigues. São Paulo: Scipione, 2002. Série Reencontro literatura.

SISTO, Celso. Textos e pretextos sobre a arte de contar histórias. ( $2^{\mathrm{a}}$ ed. revista e ampliada). Curitiba: Positivo, 2005.

SLADE, Peter. O jogo dramático infantil. São Paulo: Sumus, 1978.

VYGOTSKY, Lev. Imaginação e criação na infância. São Paulo: Ática, 2009.

\section{NOTAS}

'Podemos dizer que a cultura tradicional é fundamentada pela tradição oral. É uma cultura regida pelo símbolo e o conto também é uma manifestação simbólica que vai ter uma função determinada dentro desta cultura, a função de armazenar conhecimento para aquela comunidade. Desta forma é certo dizer que o conto na cultura tradicional está fundamentado de maneira diferente do conto na cultura ocidental, já que a cultura ocidental é regida pela escrita. Mas ele está presente em ambas.

ii Vale ressaltar que segundo a Bíblia Jesus Cristo pregava através de parábolas, ou seja, contando histórias e usando metáforas.

iii Heliodora, Barbara (2014). A Evolução de Shakespeare. Disponível: https://www.youtube.com/watch?v=e9rs2Dgpl98 - acessado em 10/09/2017. 
iv A Socìetas Raffaello Sanzio é uma companhia italiana com sede na cidade de Cesena, foi criada no ano de 1981 por Romeo Castellucci, Chiara Guidi, Claudia Castellucci e Paolo Guidi.

*Flávia Janiaski Vale é Doutoranda em Artes Cênicas pela UFBA. Mestre em Teatro pela Universidade do Estado de Santa Catarina - UDESC e Graduada em Artes Cênicas pela mesma universidade. Trabalhou como Professora Colaboradora na mesma instituição na área de Teatro Educação e Produção Cultural. Além de trabalhar com Produção Cultural em diversos projetos Municipais e Estaduais e trabalhar como produtora da Harmônica Arte e Entretenimento. Tem experiência em Artes, com ênfase em TeatroEducação, Produção Cultural, Contação de História, Orientação de Estágio, Improvisação e Montagem Teatral. Atualmente é Professora Adjunta da Universidade Federal da Grande Dourados (UFGD) no Curso de Licenciatura e Bacharelado em Artes Cênicas, está como Coordenadora Pedagógica do Curso, e presidente da Comissão de Estágio Supervisionado do Curso de Artes Cênicas ? COES/Artes Cênicas, além de Coordenar o SubProjeto de Teatro do Programa Institucional de Bolsa de Iniciação à Docência (PIBID)/UFGD.

Artigo submetido em: 06/08/2018

Aprovado em: 05/02/2019 